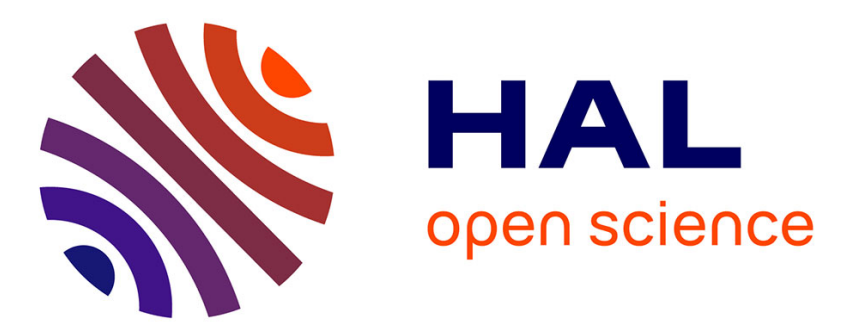

\title{
Intellectual property rights on creativity and heritage: the case of the fashion industry
}

Christian Barrère, Sophie Delabruyère

\section{To cite this version:}

Christian Barrère, Sophie Delabruyère. Intellectual property rights on creativity and heritage: the case of the fashion industry. European Journal of Law and Economics, 2011, 32 (3), pp.305-339. 10.1007/s10657-011-9230-2 . hal-02615221

\section{HAL Id: hal-02615221 \\ https://hal.science/hal-02615221}

Submitted on 22 May 2020

HAL is a multi-disciplinary open access archive for the deposit and dissemination of scientific research documents, whether they are published or not. The documents may come from teaching and research institutions in France or abroad, or from public or private research centers.
L'archive ouverte pluridisciplinaire HAL, est destinée au dépôt et à la diffusion de documents scientifiques de niveau recherche, publiés ou non, émanant des établissements d'enseignement et de recherche français ou étrangers, des laboratoires publics ou privés. 


\section{Christian Barrère Sophie Delabruyère}

Université de Reims Champagne Ardenne

\section{Intellectual Property Rights on Creativity and Heritage: The Case of the Fashion Industry}

in

\section{European Journal of Law and Economics$$
\text { 2011, vol 32.3, pp. 305-319. }
$$ \\ https://doi.org/10.1007/s10657-011-9230-2}




\title{
Intellectual Property Rights on Creativity and Heritage: The Case of the Fashion Industry
}

\section{Christian Barrère, Sophie Delabruyère OMI, University of Reims.}

\begin{abstract}
Recently, as different projects aiming to define and reinforce property rights in the fashion industry have been elaborated and discussed, a lot of papers have been dedicated to the question of property rights in this industry. Our paper considers the problems from a specific point of view; it focuses on the relation between property rights and creativity. If property rights allow the allocation of the majority of standard industrial goods without any special difficulty, however, when they are applied to creative goods, new problems arise. Then, for us, the persistence of a low system of IPRs in the fashion industry does not mainly derive from its efficiency but from the characteristics of the inputs that are used in the creative production process. They constitute strong constraints for defining, entitling, legitimating, enforcing, valuating and exchanging property rights. Thus, the different economic actors develop different kinds of strategic behaviour in order to obtain earnings and can try to protect copyrights, trademarks, new assets, old assets (heritage), private or collective assets, and so on. The institutional characteristics of this specific industry - such as the models of management, the type of ownership, the size of the firms, ... - lead to different historical models of management through IPRs. Peculiarly, the financial groups that integrate fashion into the new luxury industries currently try to implement new IPRs and to move towards a stronger system of IPRs but the management model of the street fashion puts an obstacle to this project.
\end{abstract}

Keywords Property Rights. Creativity. Heritage. Fashion Industry.

JEL Classifications K11 . K13 . K42 . O34 
Property rights allow the allocation of the majority of standard industrial goods without any special difficulty ${ }^{1}$. However, when they are applied to creative goods, new problems arise. The more important the part of creativity in the production is, the easier the infringement of PR seems to be. The "Second Life" world, a new and wonderful case of pure creativity, gave us a funny indication. Here you cannot produce goods but you can create and sell your creations. Creativity is the main reason for competition. So, by selling original houses Anshe Chung, a virtual architect, has become the first creator to earn a billion dollars. Legal problems about property rights arose however and the first court cases came up in 2007. Kevin Alderman sued John Doe for copyright violation (concerning the well-known Eros SexGen bed). Since 2005 Alderman has been selling on Second Life several thousand of this erotic bed at the price of 45 \$ US while Catteneo decided to sell a copy for 15 \$ US. In the same line, conflicts around trademarks, real and virtual, often counterfeited, are multiplying. The higher the ratio of the creative component in a good is, the higher the probability of piracy is (Benghozi and Santagata, 2001).

If property rights exist in a purely creative world the case is even more complicated when creativity joins up with industry and the mass production of luxury groups that aim at making money. This is the case of the fashion industry. Another fuzzy case of copying illustrated the complexity of defining and enforcing IPR in this industry. In 2009, Nathalie Atkinson, a Canadian journalist, shown that Diane von Furstenberg, a famous fashion designer, but mainly the head of the Council of Fashion Designers of America which was lobbying to increase the legal protection of fashion industry, appeared to have copied the work of a more obscure designer (Atkinson, 2009).

Only a few articles had been written on the problem of property rights in the fashion industry until the recent debates about the adoption of several bills (H.R.5055 in 2006, H.R.2033 and S.1957 in 2007, H.R.2196 in 2005, and S.3728 in 2010) aiming at introducing protection of fashion designs in U.S. Copyright Law. But from the beginning of the diverse lobbying actions a lot of scholars' papers, of professional declarations and individual points of view (mainly through internet blogs) arose. They generally used the standard and formal framework of Law and Economics analysis and discussed the efficiency of IPRs in this industry in relation to copying and piracy. They all observed the weakness of IPRs whatever country. Some of them criticized this weakness but others proposed a more interesting analysis - the piracy paradox - according to which there was at present a low IPR equilibrium.

These articles chaired mainly the discussion within the mental framework of the American case. The first aim of our paper is to add to it some observations based on the French case, which is important here because the Haute Couture system is a French invention and has been the first place where IPR problems emerged and lead to different systems of IPR management. Moreover, it is the first time in France that financial groups of luxury goods (such as LVMH -Louis Vuitton Moët Hennessy- and PPR -Pinault Printemps Redoute-) have succeeded in integrating the apparel system in a larger set, the set of luxury goods, and have tried to implement a new model of IPR management.

The second aim is to focus on the relation between IPRs and the two main inputs of the fashion process, creativity and heritage. We think that PRs are not a formal and general system that can be directly used for managing the allocation of any resource, whatever its specific characteristics are, everywhere and in any circumstance. On the contrary, a 'substantivist' point of view focuses on these characteristics that in a part explain the present configuration of IPRs

1 We thank the anonymous referee who sent us detailed remarks that obliged and allowed us to reinforce the quality of the paper by considering new substantial points on Law and Economics. 
in each case, particularly in the case of the fashion industry, and the diverse types of IPR management. As the productive characteristics of the creation process in fashion do not allow to use the model of perfect property rights, actors try to change the forms of property where creativity appears in order to obtain a better protection of their rights. Through managerial and institutional creativity they can modify the configuration of IPRs or/and their profit strategies (Alchian and Demsetz, 1973; North, 1981; Nelson and Winter, 1982).

Considering the role of creativity and heritage in the productive process of the fashion industry will exploit the heritage approach developed in the analysis of cultural heritage (Towse, 2010; Santagata, 2002, 2006), cultural and creative commons (Ostrom, 1990; Madison, Frischmann and Strandburg, 2010), and in the conceptualisation of heritage (Barrère et alii., 2004; Barrère, 2005, 2007a, 2007b).

In the first point we consider the legal situation of the fashion industry and in the second one the present debate on the existence of a low IPR system. Then we try to explain our observations by considering the specificity of the fashion industry: the point 3 establishes the fundamental role of creativity in the fashion creation and the 4 infers from the specific characteristics of the cultural inputs of fashion some difficulties to use the standard IPR model. These problems explain the features of both historical models of management of creative assets and IPR in the fashion industry: the classic model (point 5) and the new model (point 6). We peculiarly draw the attention on the new relations between the creative core of the fashion industry - the top segments of Haute Couture and luxury ready-to-wear - and the new segment of the street fashion. Some concluding remarks follow.

\section{The legal situation of fashion industry: a low PR system}

Although different legal tools of intellectual property can be formally applied to fashion goods and designs, protection is weak, peculiarly in the Unites States, and, even when legal tools are more sophisticated, they are underutilized.

\subsection{Different tools of intellectual property: what about fashion industry?}

Intellectual Property Law offers different tools to protect creations. Which ones are relevant to provide protection to the creations of the fashion industry? ${ }^{2}$

The first intellectual property tool to be considered is the copyright. Copyright is intended to protect the works of mind such as artistic and literary creations - music, paintings, sculptures and books, for instance. To enjoy this protection, the creation has to be original; no application is required as the copyright arises automatically with the creation itself. According to the copyright systems, fashions creations can benefit from copyright protection. In France, as in the European Union, for example, the status of "applied arts" is given to fashion creations and thus these latter are copyrightable. On the contrary, in some countries as the United States, copyright law does not protect "useful articles", and therefore articles of clothing are considered as non-copyrightable. Nevertheless, in some cases of useful articles, if the aesthetic elements look like works of art that can be identified separately from the utilitarian aspects of the product and that can exist independently of them, then the aesthetic work can be copyrighted. The main problem is that, in most cases, fashion products, and more particularly clothing ones difficultly pass the test of separability on which their copyrightable feature depends.

What about trademarks? Trademarks are distinctive signs (words or symbols) that can be affixed on products to indicate their origin to the consumers. But, "in contrast to copyrights and

\footnotetext{
2 Cox and Jenkins (2005), Schmidt-Szalewski and Pierre (2007).
} 
design patents, which are used to protect the artistic and ornamental aspects of a product, trademarks protect only the link between the product and its source, not the product itself" (Cox and Jenkins, 2005, 12). Creators in the fashion industry largely use trademarks, but their utility, particularly as regards the protection against copying, depends on their visibility. Indeed, as in the cases of the Burberry's distinctive plaid and the "LV" letters of Louis Vuitton covering handbags (Hallet, 2008), or the red tab on the back pocket of Levi Strauss's jeans, trademarks are particularly useful when they clearly integrate the design of the products. On the contrary, for most clothing articles, since the trademarks are not directly visible (when used on the buttons, for instance, or on the tabs), they do not take part of the design. So trademark law can serve to prevent counterfeiting of products in the fashion industry, but it cannot prevent copying of fashion design.

Is trade dress protection more appropriated to fashion products? Trade dress involves the total image of a product and thus includes its size, shape, color(s), graphics and texture. These features considered in trade dress (the packaging) must permit to identify the origin of the product. One significant example is the McDonald's happy meal box. As "standard is hard to meet in fashion industry, especially by new designers due to costs, time and uncertainty" (Hallet, 2008), trade dress seems to afford little protection to clothing products.

And what about patent? The patent confers an exclusive right, a temporary monopoly (20 years in Europe, 17 years in the United States) on its holder. Granting this temporary monopoly aims at encouraging research and innovation by guaranteeing that the producer will profit from his invention. To be patentable, a product has to be new and useful. The novelty feature seems to be difficult to meet in the fashion industry, unless creating a new kind of clothing really distinct from the existing ones. So for lack of protecting fashion products themselves, patent could protect fashion designs, i.e. only the ornamental features of the product, on the condition that these latter are novel and nonobvious. "Few new designs on the market are truly exceptional in form. But since difference is assessed by one-to-one comparisons, a single distinguishing feature - such as an embroidered jeans pocket, an oversized zipper or a dominant print - may be enough to produce a unique overall impression and justify the protection either of the extraordinary feature or of the whole item" (Fischer, 2008, 13). However, since in the fashion industry, designs are sometimes re-working of previous designs, and because of the expensive and long process of preparation for a patent application, the scope of design patent seems to be limited in fashion.

Among the different tools of intellectual property, the protection of designs and models appears in many respects as the most relevant one for the fashion industry. An overview of the different protections granted to fashion products in force across the world also shows that designs are the main form of intellectual property protection, even if the protection degrees differ.

\subsection{An historically lower protection in the United States than in other countries}

Fashion products and designs are granted much more protection in France, as in the European Union, than they are in the United States.

Traditionally, in the United States, copyright protection ${ }^{3}$ is denied to fashion designs on the ground that garments are "useful articles" for most of which the utilitarian aspects cannot be identified separately from the pictorial, graphic or sculptural features that are eligible for

3 The Copyright Act, enacted in October 1976, provides the basic framework for copyright law in the United States. This Act and the subsequent amendments to copyright law are contained in Title 17 of the United States Code. Hereafter, we denote it as U.S. Copyright Law. 
copyright protection. Nevertheless, for a few years, debates have intensified on the need for legislation granting protection to fashion designs. In the current $111^{\text {th }}$ Congress, two bills have been introduced to propose such an evolution towards fashion design protection. The Design Piracy Prohibition Act (H.R. 2196, introduced in April 2009) and the Innovative Design Protection and Piracy Prevention Act (S. 3728, introduced in August 2010) contain proposals amending chapter 13 ("Protection of original designs") of U.S. Copyright Law 4 . If enacted, these acts would provide a three-year term of copyright protection for both "the appearance as a whole" and the ornamentation of articles of apparel (broadly defined as articles of clothing, undergarments, handbags, and eyeglass frames $)^{5}$. The protection against infringement without the consent of the owner of the design would concern both the image of the fashion designs and the designs themselves. Unlike with the bill S. 3728, protection granted by H.R. 2196 would require fashion designs to be registered to the Copyright Office.

As long as these bills are not enacted, fashion producers cannot protect the overall appearance of their creations and designs from the copyists. In the meantime, the United States Code permits fashion houses, as other producers, to benefit U.S. Trademark Law. According to the Chapter 22 "Trademarks" of Title 15 "Commerce and Trade" of U.S. Code, fashion producers can protect the names and logos affixed on their products. The registration of a trademark remains in force for ten years, and may be renewed for periods of ten years. In such a context of lack of protection for designs, fashion designers are incited to incorporate the logos of the trademarks in their designs, in order to protect them from copying.

In France, unlike in the United States where clothing garments are mainly regarded as useful articles, fashion articles and designs receive more protection. Indeed, since the law of 19 and 24 July 1793 on artistic works, fashion is considered as an "applied art" and, as such, articles of fashion have an intermediate status between two kinds of creations, the exclusively utilitarian ones and the creations with exclusively an aesthetic form (Schmidt-Szalewski and Pierre, 2007, 145). For example, a drawing on a dress has a utilitarian feature with an aesthetic form. This twofold character of fashion articles, as of industrial arts, is the main reason why, under the French system, their legal protection can fall both within the industrial property with designs law and within the literary and artistic property with the "droit d'auteur". According the "unity of art" approach established in French law by the law of 14 July 1909 on designs and models 6 , a creator can enjoy - simultaneously or not - protection of "droit d'auteur" and design protection, both codified in the Code of Intellectual Property (CIP)7. On the one hand, "the creations of the industries of seasonal textile and of finery" are considered as "works of mind" and, as such, are works that can be protected by "droit d'auteur" (CIP, article L.112-2 §14). The "droit d'auteur" arises from the creation of the work and does not require any registration. On the other hand, "the appearance of the whole or a part of a product, characterized by its lines, contours, colours, shape, texture or materials", for the fashion product itself and its ornamentation, can be protected as "models or designs" (CIP, article L.511-1). To grant this protection, designs must be new and give an overall visual impression different from known

4 Similar bills intended to protect fashion designs were introduced in the $109^{\text {th }}$ Congress (H.R. 5055, in 2006) and the 110 10 Congress (H.R. 2033 and S. 1957 in 2007), but they were not enacted.

5 For an analysis of these two bills, and their differences, see Yeh (2010).

6 At the European level, this approach was established with the Directive 98/71/EC of the European Parliament and of the Council of 13 October 1998 on the legal protection of designs.

7 In the First part of the Code ("literary and artistic property"), 1st book for "Copyright"; in the Second part ("Industrial property"), 5th book for "Designs and models". 
designs (CIP, articles L.511-2, L.511-3, and L.511-4), and have to be registered with the National Institute of Industrial Property (NIIP) (CIP, articles L.511-9 and L.512-1). The design protection lasts for a minimum of five years, renewable for additional periods of five years until a maximum of twenty-five years (CIP, article L.513-1).

Currently, in French Law, fashion creations are not particularly set apart from other products granted with protection of "droit d'auteur" or with design protection. However, in the past, they enjoyed a special status with specific laws. In particular, fashion was concerned with two specific laws ${ }^{8}$. First, as designs and models were not considered in the above-mentioned law of July 1793, Napoleon got a law adopted on 18 March 1806 to create an industrial tribunal in Lyon intended to organize the protection of registered designs of the textile industry. But, this law was abrogated by the law of 14 July 1909 on designs and models. A second specific law was adopted on 12 March 1952 (law n52-300). It aimed at suppressing counterfeiting of the creations of the industries of seasonal textile and of finery. For forty years, this law of 1952 gave a particular regime of protection to fashion creations, until it was abrogated by the law $\mathrm{n}^{\circ}$ 92-597 of $1^{\text {st }}$ July 1992 concerning the Code of Intellectual Property. The gist of this abrogated law is henceforth in the article L.112-2 of CPI concerning protection of "droit d'auteur".

In addition to the protection granted to their designs, fashion houses can also protect their trademarks. To be concerned by the French trademark law ${ }^{9}$, the distinguishing feature has to be registered with the NIIP (CIP, article L.712-1). At present, the NIIP counts 262424 French trademarks for products of class 25 ("Clothing, footwear, headgear") of the Nice Classification ${ }^{10}$. The registration, in force for ten years and indefinitely renewable, confers on its proprietor exclusive rights on the trademark for the products concerned and forbids any reproduction and use of the trademark without the consent of its owner (CIP, articles L.713-1 and L.713-2).

Within the European Union, protection of intellectual property in the fashion industry comes both within trademark protection and design protection.

On the one hand, fashion producers can benefit from the protection granted to the Community trademarks, as established by the Council Regulation $n^{\circ} 422 / 2004$ of 19 February 2004 amending Regulation (EC) $\mathrm{n}^{\circ} 40 / 94$ on the Community trade mark. Requiring only a single application to the Office for Harmonization in the Internal Market (OHIM), the Community trademark produces the same effects throughout the Community. The proprietor is entitled to prohibit all persons from using, in the course of trade, any sign which is identical with the Community trademark in relation to goods identical with those for which the Community trade mark is registered, and any sign similar to the registered Community trademark because of the likelihood of confusion on the part of the public (mainly likelihood of association between the sign and the trade mark) (above-mentioned Regulation, article 9).

On the other hand, within the European Union, fashion houses can also use the Community protection for their designs. Fashion designs can benefit from the uniform system of design protection that has been established with the adoption of the Council Regulation

\footnotetext{
${ }^{8}$ For a more detailed history of design protection in France, see for instance Schmidt-Szalewski and Pierre (2007, 146-147).

${ }_{9}$ Codified in the 7 th book of the Code of Intellectual Property.
}

10 The Nice Classification is an international classification of goods and services applied for the registration of trademarks. The Nice Agreement concerning the International Classification of Goods and Services established it for the Purposes of the Registration of Marks concluded in 1957. The current edition of the classification (the ninth one), consisting of a list of 35 classes, entered into force on January $1,2007$. 
$n^{\circ} 6 / 2002$ of 12 December 2001 on Community Designs, entered into force on 6 March 200211 . To be qualified as a "community design" having the same effects and protection within all the 27 Member States of the European Union, a design ${ }^{12}$ (and then a fashion design) must be new and have an individual character (above-mentioned regulation, articles 4, 5 and 6). The European Regulation provides for two kinds of protection for such community designs, and thus to fashion community designs, according to the design has been registered or not with the OHIM. The "unregistered community design" benefits from a short protection. Without any formality, for a period of three years from the date on which the design was first made available to the public within the European Union, the design is protected against deliberate copying (Regulation $n^{\circ} 6 / 2002$, articles 11 and 19\$2). The protection granted to a "registered community design" is longer. For a minimum of five years (to a maximum of twenty-five years) since the date of the filing of the application with the OHIM, a registered design is protected against both deliberate copying and the independent development of a similar design in any of the 27 countries of the European Union (above-mentioned regulation, articles 12 and 19§1).

At the international level, several agreements deal with the protection of intellectual property, either in a global frame or in the specific frame of trademarks and of designs and models ${ }^{13}$, and can - explicitly or implicitly - concern the fashion industry.

The first international agreement that should be mentioned is the Agreement on TradeRelated Aspects of Intellectual Property Rights (TRIPs), negotiated in the 1986-94 Uruguay Round of the World Trade Organization (WTO) ${ }^{14}$ that, for the first time, introduced intellectual property rules into the multilateral trading system. The WTO's TRIPs Agreement aims at narrowing the gaps in the way the intellectual property rights are protected and enforced around the world. To do so, it sets minimum levels of protection that each signatory government must provide for the various types of intellectual property tools. Industrial designs, and in particular fashion designs, are concerned with these measures. Thus, article $25 \S 2$ states that "each Member shall ensure that requirements for securing protection for textile designs, in particular in regard to any cost, examination or publication, do not unreasonably impair the opportunity to seek and obtain such protection. Members shall be free to meet this obligation through industrial design law or through copyright law"15. According article 26, the duration of protection available shall amount to "at least 10 years".

Secondly, at the international level, fashion producers can be concerned by the Madrid system for the international registration of marks established in 1891 and functioning under the Madrid Agreement of 1891 and the Madrid Protocol of 1989. Administered by the International Bureau of WIPO, the Madrid system offers an international procedural mechanism, that allows a trademark owner the possibility to have his trademark protected in several countries by filing a single application directly with his own national or regional trademark office ${ }^{16}$. Thus the

11 The Directive 98/71/EC of the European Parliament and of the Council of 13 October 1998 on the legal protection of designs initiated the harmonization process of national legislations on design protection, but the designs still had to be registered in the Member states with the competent authorities.

12 i.e. "the appearance of the whole or a part of a product resulting from the features of, in particular, the lines, contours, colours, shape, texture and/or materials of the product itself and/or its ornamentation" (Regulation n6/2002, article 3).

${ }^{13}$ For more details, see Schmidt-Szalewski and Pierre (2007, 459-518).

14153 countries are members of the WTO.

15 The adaptation of the TRIPs Agreement in French law results from the law n ${ }^{\circ} 96-1106$ of 18 December 1996. At the European level, the WTO agreement was passed by the Council decision n94/800 of 22 December 1994.

1656 countries are parties of the Madrid Agreement. 
Madrid system offers a route to trademark protection in multiple countries and simplifies the subsequent management of the mark.

The third international agreement to be considered is the Berne Convention for the Protection of Literary and Artistic Works of September 9, 1886 ${ }^{17}$. Although fashion designs are not explicitly mentioned in the list of "literary and artistic works" (article 2), they seem to be implied as "works of applied art" are concerned.

Lastly, let mention the Hague Agreement of 6 November 1925, revised by the Geneva Act of 2 July 1999. Since 2004, the Hague system for the International Registration of Industrial Designs ${ }^{18}$, administered by the International Bureau of WIPO, provides a mechanism for registering a design in countries and/or in intergovernmental organizations that are party to the Hague Agreement ${ }^{19}$. This system offers a simplified registration system to the owners of industrial designs: the latter obtain protection for their designs in all the member countries of the Geneva Act only by filing one single application for registration with the International Bureau of WIPO. Such an international registration of design has the same effects in each of the designated countries in the Geneva Act, as if the design had been registered directly with each national office, unless the national office of one country refuses this protection.

\subsection{Underutilization of IP protection in fashion}

Among the different tools of intellectual property, the protection of industrial designs is the most relevant one for the fashion industry. But little use is made of registration of fashion designs. How can this underutilization of intellectual property protection in fashion be explained?

A review of the evolution of registrations of designs products under class 2 ("articles of clothing and haberdashery") of the Locarno Classification ${ }^{20}$ clearly indicates a low utilization of design registration process in the fashion industry at the international level (see table 1 below) ${ }^{21}$. In 2009, in France, the National Institute of Industrial Property registered 2811 designs for "articles of clothing and haberdashery" (18,7\% of total registrations), the Office for Harmonization in the Internal Market registered 8192 designs for class 2 (11,6\% of total registrations), whereas the International Bureau of the World Intellectual Property Organization dealt only with 62 designs for the same class (only 3,7\% of total registrations). In the fashion industry, a few firms - most of time, small and medium ones - register their designs (Hallet, 2008).

Table 1

Registrations of designs of products under class 2 of the Locarno Classification by Office

\footnotetext{
17 Revised several times: at Berlin in 1908, at Rome in 1928, at Brussels in 1948, at Stockholm in 1967, and at Paris in 1971.

1857 countries are parties to the Hague Agreement.
}

19 The Hague Agreement comprises three different Acts (the London Act, the Hague Act and the Geneva Act) each of which consisting of a distinct set of legal provisions. The Geneva Act signed on 2 July 1999 and operational on 1 April 2004 is the latest one. The European Community acceded to the Geneva Act of the Hague Agreement on 24 September 2007, and the Act entered into force within the European Union on 1 January 2008.

20 In their registers of designs, offices of registration, as the International Bureau of the World Intellectual Property Organization (WIPO), and the Office for Harmonization in the Internal Market (Trade Marks and Designs) (OHIM), use the Locarno Classification consisting of a list of classes (32) and subclasses (219). The Locarno Agreement Establishing an International Classification for Industrial Designs was signed at Locarno on October 8, 1968 and amended on September 28, 1979. The current edition of the classification (the ninth one) entered into force on January 1, 2009.

21 Most of registrations concern products of class 6 ("furnishing") and products of class 9 ("packages and containers for the transport or handling of goods"). 
Annual statistics and proportions in total of registration 22

\begin{tabular}{|c|c|c|c|c|c|c|c|}
\hline Office of registration & 2003 & 2004 & 2005 & 2006 & 2007 & 2008 & 2009 \\
\hline $\begin{array}{l}\text { National Institute of Industrial Property } \\
\text { (France) }\end{array}$ & 1959 & 2078 & 2702 & 2205 & 1969 & 2431 & 2811 \\
\hline$\%$ of NIIP's total annual registrations & $11,9 \%$ & $12,4 \%$ & $16,8 \%$ & $15 \%$ & $13,8 \%$ & $18 \%$ & $18,7 \%$ \\
\hline $\begin{array}{l}\text { Office for Harmonization in the Internal } \\
\text { Market (European Union) }\end{array}$ & 3156 & 4013 & 5426 & 6430 & 7631 & 7638 & 8192 \\
\hline$\%$ of OHIM's total annual registrations & $8,29 \%$ & $7,39 \%$ & $8,51 \%$ & $8,98 \%$ & $9,54 \%$ & $9,63 \%$ & $11,58 \%$ \\
\hline $\begin{array}{l}\text { International Bureau of the World } \\
\text { Intellectual Property Organization } \\
\text { (under the Hague System) }\end{array}$ & 93 & 49 & 38 & 27 & 29 & 55 & 62 \\
\hline \% of WIPO's total annual registrations & $3,74 \%$ & $3,47 \%$ & $3,34 \%$ & $2,36 \%$ & $2,53 \%$ & $3,61 \%$ & $3,7 \%$ \\
\hline
\end{tabular}

Several elements can explain these small numbers of registrations of fashion designs. The first one is that "most of the designs registered by fashion houses are not for clothing [class 2], but for accessories - watches, bags, sunglasses, etc., which fall under several different Locarno classes" (Fischer Fridolin, 2008, 13). However, the main explanations for underutilization largely depend on the features of the fashion industry and its products and on the costs of registration process. The seasons in fashion are really short, only a few months (WIPO, 2005, 16), whereas the protection granted with registration lasts at minimum five years. "The majority of fashion designers consider that, with fashion seasons lasting only a few months, the five-year minimum protection period offered by these registration systems is not appropriate for often ephemeral fashion designs, and that their time and money would therefore be better spent on creating new designs than on registration" (Fischer Fridolin, 2008, 13). In such a context, the three-years protection provided within the European Union for non-registered designs proves to be particularly relevant.

The conclusion is clear: in the fashion industry IPRs are low; moreover, all the specialists (see for France, Grumbach, 1993; for USA Litman, 1994, Raustalia and Sprigman, 2006) agree with this point.

\section{The debate on IPR efficiency}

How to interpret the weakness of existing PR? Economists used economic theory to interpret it within the standard framework of IPR efficiency in relation to copying and piracy. A first group of authors criticize this weakness and claim for a strong IPR system (for example, Terakura, 2000; Hetherington, 2001), either to strictly define them or to strongly enforce them. They suppose that new legal rules can be extended to fashion field and increase the efficiency of the IPR system, as the promoters of the Design Piracy Prohibition Act in the United States believe. An adverse position considers that fashion has reached its equilibrium because a system of low IPR would be the efficient one. This more original analysis is justified through the general idea that imitation is necessary or at least useful to decrease economic uncertainty in the fashion sector and, thus, is efficient. It is developed in the line of "the piracy paradox" (Raustalia and Sprigman, 2006) and "the cooperative innovation model" (Barnett, Grolleau and El Harbi,

22 Sources: designs database on NIIP's website; annual Statistics of Community Designs on OHMI's website; International Designs Bulletin, annual statistics on WIPO's website. 
Even if this analysis is attractive, for us it cannot explain the whole set of observations. So, after considering this opinion, we will develop another hypothesis. The weakness of IPR is then related to the substantive characteristics of production process in the fashion field. In this industry, and mainly in the segment of the Haute Couture, the purpose of producers is not to improve but to create. Creations remain unique and are non-cumulative knowledge escaping from the incremental character of technical progress. Creative products and their main inputs, creativity and heritage, thus have a strong cultural and economic value and standard efficiency considerations would lead to implement a high and enforced system of IPRs. Nevertheless creativity and heritages cannot be easily protected as they include a cultural commons dimension. It is this intrinsic property that prevents IPR from happening.

Raustalia and Sprigman argue "that the fashion industry counterintuitively operates within a regime of free appropriation in which copying fails to deter innovation and may actually promote it. We call this the 'piracy paradox'." (Raustalia and Sprigman, 2006: 5). Two main arguments are used. The first relates to induced obsolescence. Piracy diffuses innovation in a positional goods world and accelerates the diffusion of designs and styles, leading to an acceleration of the renewal of goods ("In short, piracy paradoxically benefits designers by inducing more rapid turnover and additional sales"). We agree with this point but we think that it does not lead to a pure acceptation of piracy. The induced obsolescence is only an externality, a global effect on the market. Nothing guarantees that the innovator will be the main beneficiary of the induced obsolescence and, from a free-riding point of view, he could take a profit from the obsolescence induced by the copying of other creators while protecting his own innovation.

The second argument is that "a low-IP regime helps the industry establish trends via a process we refer to as "anchoring". Our model of anchoring rests on the existence on definable trends... Copying does this by anchoring the new season to a limited number of design themes... Thus anchoring helps fashion-conscious consumers understand (1) when the mode has shifted, (2) what defines the new mode, and (3) what to buy to remain within it" (Raustalia and Sprigman, 2006: 45). The cooperative innovation model (Barnett, Grolleau and El Harbi, 2010) develops this basic idea in a more sophisticated way. The authors would found on an economic model of the industry the efficiency of low and unequal PR (strong trademark protections and weak copyright, trade dress and design protections). For them, fashion firms encounter a strong "fashion risk" if they miss any reliable indication of the next fashion trends. Fashion industry belongs to creative industries where the main rule is "nobody knows". Then firms built a development path based on cooperation in the definition of the products by accepting imitation and organizing unequal enforcement of IPR: "jurisdictions effectively operate under an incomplete property regime consisting of three elements: (i) strong protection against trademark infringement (i.e., counterfeits...), (ii) weak to moderate protection against literal or near-literal design infringement (i.e., close knockoffs...), and (iii) no protection against non-literal design infringement (i.e., not-so-close knockoffs and other "inspired" derivative products" (2010: 10-11). If we agree with the statement of fact, another interpretation seems better.

For the time being there is no undisputable conclusion as regards to the efficiency of a low IPR system, which would suppose a comparison of a low and a high IPR system. A fashion system existing with low IPRs does not signify that low IPRs are the best system, and are the best system regardless of the organisational characteristics of the industry.

To understand the relation between IPRs and fashion we have to precisely consider the relations between Haute Couture and the other segments of the fashion pyramid in the production process. The imitation argument misses the difference between copying within the 
creators' circle and the copy of creators' products by the ready-to-wear or the mass market producers (the street fashion way). Let us take the French case. The fashion industry has a production core and peripheral components: creators of garments, producers of garments, detailers, managers, experts and critics and so on. The production core has a pyramidal form, according to prices and quality, and contains four main levels:

-1 the top of the pyramidal model of the French fashion is the Maisons de couture, i.e. the segment of the Haute Couture. Few creators (Karl Lagerfeld, Christian Lacroix, Jean-Paul Gaultier, ...) work at the same time and, preparing a new collection, cannot copy each other. For them the fashion risk is not the risk to miss the trend. The trend is not very important and is made out of their self-imitation. Their problem is to propose very diverse collections, each one being related to a defined style: Gaultier is not interested in copying Lagerfeld because they have two very opposite styles. The length of the dresses, the dominant colours, and the selected raw materials concern the fashion trends. Two institutions, the "cabinet de tendances" and the fabric makers define all that; without any imitation everybody can know what will be the fashion trends ${ }^{23}$. But it is a very small problem and it does not affect the core of the creative process. On this common basis the problem of creators is to differentiate their creations according to the style of the Maison and imitation is out of consideration. If some creations of the Haute Couture have some proximities they do not derive from copying but from other mechanisms: all the creators are immerged in the same cultural "mood"; they all choose within a limited set of new fabrics, the designs of which are close to and often derive from the "cabinets de tendances". And, if there is "copying" or "meeting", these processes do not concern the designs (the Chanel's or the Galliano's style) but some general properties: the length of the skirts, the dominant colours, ... So, anchoring does not concern the top of the pyramid. Moreover the used notion of fashion risk does not apply to the Haute Couture system. They are not organized to make money but to develop creativity and image, then reputation, which will be used in the other segments of luxury industries (Barrère and Santagata, 2004).

-2 the quality and creative ready-to-wear constitutes the second segment of the pyramid. A first part of the products come from the Maisons as euphemized declination of Haute Couture models. A second part comes from style firms, generally small. They use the creativity of the grands couturiers and of the stylists. Here imitation may intervene: other creators may use some innovations or new designs of the Haute Couture collections or of the small creators as inspiration.

-3 other small and flexible firms belong to a third segment, the standard ready-to-wear. Even if they employ stylists, they use less creativity. They may develop their own creativity but they also can avoid costs of creativity by copying the creativity of the previous segments. Then, they behave as free riders. The rate of imitation may be more or less important. They only can use other creations as a source of inspiration or adopt some of their characteristics. They also can sell the imitated products with reference to these creations, using therefore their reputation. It is not really counterfeits as in the accessories production. Prices, distribution networks, trademarks are generally different from original creations, and consumers know that they do not buy an original product. But, doing so, they benefit from the investment in creativity of others; they use for them a part of the reputation capital created by the first designers and a part of their investment to tempt and persuade consumers to buy the model in question. It is the story told by Narciso Rodriguez before the Subcommittee on Courts of the U.S. House of representatives: "The story I'm about to tell you is one of the reasons that I am before this subcommittee today urging that you pass a law to prohibit piracy of fashion designs. Back in 1996 one particular

${ }^{23}$ Another problem is to know if the audience will agree with the previous institutional choices. 
dress put me on the fashion map. My good friend Carolyn Bessette (whom I met while working at Calvin Klein), asked me to design her dress for her marriage to John F. Kennedy, Jr. That dress became the most copied silhouette of the past decade. The pirates sold around 7 million or 8 million copies. I sold 40. I used a special technique to complete that look and it is part of my signature style that I had been developing since I was quite young. There was a lot of construction and special placement of seams involved even though it looks quite simple.It's a technique that fellow designers have learned from. The first group of copies the pirates released weren't sophisticated, but then, a magazine reprinted the correct sketch of the dress and far superior copies were produced. Those dresses were sold using my name, and using the Kennedy name. Some may say that I benefited from the publicity; publicity with no sales does not pay the bills".

-4 the fourth segment concerned by the infringement of IPR is the street fashion. The main firms are, today, big and globalised firms operating on a large scale: H\&M and Zara are the most famous. They developed a new business model based on a new production model. They scrutinize the new designs and adapt them to cheap production. They keep the designs and used them with cheaper fabrics. That, however, mainly regards the mass market.

Then, copy and piracy are very general words the meaning of which may be very different according to the concerned firms. Indeed, in the legal and economic literature dealing with intellectual property rights in the fashion industry, several terms are used to refer to the imitation and copying strategies: "copyists", "close copying", "participation in common trends", "inspiration", "adaptation", "homage", "referencing”, "remixing", "borrowing”, "reference", "fakes", "counterfeits", "knockoffs", ...24 To clarify the question, we begin by identifying the resource the protection of which is the main stake; after, we will consider the problems this protection encounters.

\section{What is protecting creation: culture as a fundamental input of production in the fashion industry}

In the fashion industry, culture intervenes as a "new" culture -culture is a flow, through creativity- and as an "old" culture -culture is a stock, through heritage. Current creativity uses the creativity of the past, which has been accumulated to constitute a heritage, and, simultaneously, adds to it. Moreover, when cultural industries use creativity and heritage simultaneously, they benefit from a virtuous circle, namely goods, knowledge, ideas produced constitute kinds of heritage that, in return, favour creativity. By mimicking Sraffa we can speak of the production of creative goods and heritage by creative goods and heritage.

Creativity (and therefore heritage) appears, in the fashion industry, in two main forms: product creativity and managerial creativity. It was mainly located in the top segment of the fashion pyramid, the Haute Couture, and then flew through the other segments (luxury readyto-wear of the creators, high quality ready-to-wear, ready-to-wear). But, today, with the incredible development of the 'street fashion' of the mass market, a new low cost model emerged.

24 Barnett, Grolleau and El Harbi (2010) suggest a taxonomy of imitation strategies in the fashion market based on three characteristics: mark, design and quality. According the degree of replication of these three characteristics, three main strategies are identified: "horizontal imitation" (equivalent to "borrow" or "reference"), "legitimate vertical imitation" (corresponding to "knockoffs") and "illegitimate vertical imitation" (such as "fakes" or "counterfeits"). 


\subsection{The managerial creativity as creative commons}

If artistic creativity is the most important in the history of fashion, creativity also concerns the management of the production and marketing processes.

The first big innovation in the fashion industry imposed a specific institutional organization, the Maison de couture (Barrère and Santagata, 2005). In the old system, the models derived from the étiquette de la Cour and the couturiers were craft workers. During the Second Empire, Charles Worth stood up as a creator, an artist and became a couturier-créateur. He defined himself as an "artiste en robes", a "compositeur de toilettes". Poiret defined clothing as a product of art.

With this innovation creativity got the upper hand over technical dexterity and the Maison de couture concentrated the origin of creativity at the top of the system. Until the fifties this system was profitable, but the economic conditions of the fashion system considerably changed and many Maisons disappeared: after the Second World War there were still 106 Maisons de couture in Paris, in 1967 only 19 and now there are less than ten. The survivors are the Maisons that have been able to introduce new managerial creativity.

Before the Second World War, Poiret was the first to understand the possibility of using his reputation to sell perfumes and accessories in order to make money. Through the system of the 'griffe', the names of famous couturiers have become widely known beyond the spheres of their direct customers, and often from a generation to another one. They greatly contributed to the market power of firms. After the War, Christian Dior connected Haute Couture and readyto-wear by creating high quality ready-to-wear. This gave birth to a new luxury ready-to-wear, the 'prêt-à-porter des couturiers et créateurs' which allowed the Maisons to expand their market.

Since the seventies the management of the market power of the Maisons has become a decisive factor by taking market conditions into consideration. The profitability of ready-towear and accessories offset the non profitability of the Haute Couture segment and a strict connection was set up between the mass production goods and the laboratory of creativity and the reputation of the top segment.

Since the end of the $20^{\text {th }}$ new strong actors of the field, the big store-chains of the fashion street, as Zara, H\&M, and Gap, developed a new managerial creativity. They created a new business model based on the observation and the marketing of demand. Firstly a lot of different products defined on a very large scope are offered to consumers. They choose some of them (the market analysts speak of a 20/80 rule, 20\% of new products are well appreciated and give $80 \%$ of the sales). Secondly the production flow has to be adapted to the more or less erratic choices of consumers. For that subcontracting and just-in-time processes are used. Thirdly super-obsolescence is organised. The traditional rhythm of the fashion collections (twice a year) is disrupted. Each fifteen days old product disappears and new arrives. Fourthly prices are low; materials are cheap but allow a standard quality and a mass production for the numerous markets of the global world. And fifthly advertisement is massive and mainly concentrated on trademark and not on products.

This new model represents an important managerial innovation, as strong as the development of the new ready-to-wear in the fifties. But it is also based on the copying of design elements that are elaborated by the higher floors of the pyramidal system of fashion. So strong forces push on constituting new creative commons. Firms and groups of the industry can apply managerial innovations developed by other ones; some actors, mainly the new street fashion groups want to impose their low cost model by transforming the product creativity of the other parts of the fashion industry into an open access common-pool resources in order to draw from it. 


\subsection{The product creativity between individuals, communities and heritages}

Haute Couture is strictly organized around creativity, its key input (Barrère and Santagata, 2005). Models and designs are not standard outputs but one-offs, yielding unique pieces of work, strictly bound up with individual talent. Competition is primarily based on creativity and not on cost reduction, while new segments of mass fashion compete through prices but on the basis of new creativity or thanks to copying the creativity in the high segments.

In standard industries there is a trend of technical progress that is incremental. Each good is likely to be substituted for a better one, a more sophisticated or a cheaper one; each technology is substituted for a more efficient one. Thus the value of "old" goods or techniques is quickly diminishing. It is not usually the case in creative industries and especially in the fashion industry.

Here there can be innovation and technical progress, in which case there can be incrementality, but this is not its dominant feature. The principle of fashion is precisely that someone may prefer the fashion of the seventies to the fashion of the sixties but nobody can maintain that one is technically superior to the other one. Creativity embodied in models and designs thus constitute a heritage of creative products, the value of which are not declining but, conversely, may grow. In the fashion system, this heritage is simultaneously a physical stock of designs and models and the cultural heritage of a style (e.g. the Chanel style). It is highly valuable because new creators can "revisit" old collections and styles and can "revisit" (now the key word of the creation process) the history of fashion. This heritage also allows customers to identify a style.

Creativity is not to decide whether a skirt has to be long or short. A creator uses a lot of common inputs and conditions: the mood of the time, the successful movies, the trends in other arts such as architecture or design, the personalities of the top stars of the moment, ... A creator is creative because his interpretation is unique; his talent is idiosyncratic. Working under the same conditions, John Galliano and Karl Lagerfeld create collections which may have some similar characteristics (the length of the clothes, the dominant colours...) but which are fundamentally different. And each one creates his collection within a style, with reference to a specific heritage.

Creativity sustains heritages of firms or of creators but it also contributes to collective heritage. In the UK, the success of Vivienne Westwood or John Galliano is linked to the tradition of English tailors (Lehnert, 2000). Creativity develops too a reputation capital that increase outlets. This capital is connected to particular firms or designers but, for a part, is a collective one. In a market of sign-goods it allowed the demand to adjust to the supply. It made fashion understandable; it made creation credible; it legitimated creative work such as fashion creation. Moreover, it provided a competitive advantage in world markets. Cultural heritage, mainly the intangible kind, influenced individual and social preferences, and consequently affected demand functions insofar as producers could generate demand for these goods through communication strategies. For instance, the demand for Dior perfumes was related at one and the same time to the image of the great Haute Couture creator, to the "French touch" and to the Parisian heritage of fashion, art and culture.

So creativity has a big value and must be protected. Moreover fashion is more and more connected to clothing and luxury industries; that increases the spread of creativity. Firstly because Haute Couture is not per se profitable but creates models and reputation that are exploited in the ready-to-wear in which some segments are mass-produced. Secondly because the Maisons de couture develop accessories (bags, shoes, ties, perfumes...) that, for the main part, belong to mass production. Thirdly because financial groups (such as the two leaders, 
LVMH of Bernard Arnault and PPR of François Pinault) enter the field and build creative groups able to intervene in all the segments of luxury industries. Specific assets of fashion creation become more and more valuable: a trademark such as Dior has a very high specific value related to the name of Dior and to the joint reputation. New groups that are using sophisticated management seek to improve the management of IPRs on these assets and to conduce to a change from the old model, the Haute Couture system based on Maisons owned by great creators (Chanel, Dior, Balenciaga...) to a new system, with a new model of management through IPRs.

Then different kinds of IPR problems appear in the fashion industry: they concern the Haute Couture, the ready-to-wear, the accessories and their relations.

For the Haute Couture there is no problem of counterfeit: even if creativity plays the key role, materials are very expansive, the cost of labour is very high and counterfeiting is not profitable. It would only be profitable if the counterfeiter substitutes low to high quality materials. Nevertheless the contexts in which both products are sold forbid that. Haute Couture products are sold through a system of personal relations, within a close circle, and in special places. If creativity is the main input of the fashion process, the question is the question of piracy. As already seen the main stake is not within the Haute Couture. It is firstly within the ready-to-wear. The difference between copying, imitation and inspiration is often very weak. Nevertheless it is in the relation between the street fashion system and the other segments of the fashion system, mainly the Haute Couture that the principal laboratory of creativity is and that the key stakes are. It is true that the business model of the street fashion intentionally takes from Haute Couture, luxury and standard ready-to-wear.

Within the ready-to-wear and mainly the luxury and creative ready-to-wear copying is possible. In some cases it is only inspiration when in others it is really piracy (remember the case of N. Rodriguez).

For the accessories the problem is twofold. The first one is counterfeiting. The question is now well known (OCDE, 1998; Benghozi and Santagata, 2001; Cox and Jenkins, 2005; Shemtov, 2007; Rutter and Bryce, 2008). The second one is piracy. Copying a success accessory while introducing a small difference is easy.

\section{How protecting creation: some difficulties to use the standard model of protection by intellectual property rights}

In the 1960s the French grand couturier Yves Saint Laurent presented a collection called "Mondrian", openly drawing his inspiration from the famous Dutch painter's work. This anecdote raises many questions about intellectual property rights. For instance, was Saint Laurent entitled to use Mondrian's paintings as a source of inspiration regardless of IPRs in Mondrian's creations, and without paying royalties to Mondrian's heirs? Could the fashion designer argue that Mondrian's paintings were a part of our common heritage and therefore free goods? Referring to "heritage" entails defining what portion of Mondrian's creation truly constitutes that heritage. Is it only his style of painting? The colours of his creations? And so on. Could we share between Mondrian's creativity and Saint Laurent's creativity? To complicate matters, a few weeks later, street fashion produced clothes of lesser quality for the ready-towear market inspired by Saint Laurent's Mondrian collection. One might question whether producers were entitled to propose a collection so "very close" to Saint Laurent creations. Did Saint Laurent's creations become a heritage that street fashion could use as a source of inspiration as much as Saint Laurent himself had done with Mondrian's paintings? 


\subsection{A perfect system of Property Rights}

By clearly stipulating who holds the rights in each economic resource, a property rights system allows for efficient management -including inter-temporal management- of the use of resources because the holders have the full benefit of their fructus. It also allows for resources to be allocated, through abusus, to their most efficient uses. This implies a well-defined system of property rights, stipulating the monopolistic boundary line around resource uses that holders of the property rights can enjoy, and, alternatively, all the uses prohibited for other people. A perfectly defined PR would be a clear definition of all the uses that holders are empowered to have in every state of nature. Formally, a PR system is a complex of relations between three sets:

- a set of title holders $\left\{\mathrm{H}_{\mathrm{i}}\right\}, \mathrm{i}=1, \ldots \mathrm{n}$

- a set of resources $\left\{\mathrm{R}_{\mathrm{j}}\right\}, \mathrm{j}=1, \ldots \mathrm{m}$

- a set of actions which is the particular uses of each resource $\left\{A_{j k}\right\}, j=1, \ldots m ; k=1$,

....z. The uses of my car are for example in going to work, going on holiday, carrying luggage, lending it to a friend, and so on.

A perfect PR system would imply that each action concerning each resource is entitled to the right of someone without any discussion and with the full consequences of those actions in any state of nature. It implies an injective application: $\mathrm{H}_{\mathrm{i}}=>\mathrm{A}_{\mathrm{jk}}, \forall{ }^{\prime i} \mathrm{i}, \mathrm{j}, \mathrm{k}$, what we can observe in a standard production function such as $\mathrm{q}=\mathrm{f}\left(\mathrm{I}_{1}, \mathrm{I}_{2}, . ., \mathrm{I}_{\mathrm{n}}\right)$. That supposes that many conditions are observed:

- we can identify all the inputs (Ii), these inputs are clearly defined as homogeneous ones and are separable

- we know the relation between each input (or the marginal quantity of input) and the output

this relation is stable

- we can measure the value of the output (vo)

If these conditions are met, we can define property rights in inputs; and the observed value of the output vo can be distributed among the contributions from each input. Starting with the observation of this vo, we can relate it to some action $A_{j k}$; from $A_{j k}$ we can infer the presence of the resource $R_{j}$ and allocate a part of the value vo to it; then it suffices to entitle someone to $R_{j}$. Each resource is entitled and each PR has a value, that of the highest value among the values of the actions entitled by the PR in the resource. Then, each input is clearly linked to a property right and property rights do not overlap. These property rights can produce efficiency. Within a production function framework, this value of the property rights is related to the productivity of the resource, and in such a way an efficient market can emerge. And, according to economic theory, property rights in inputs must be defined to improve efficiency.

Unhappily the production process of the fashion industry does not use a standard production function; a lot of problems follow from this specificity.

4.2 Why does creativity make it difficult to implement PR?

As far as creativity and heritage are concerned, they are special inputs and they do not generally satisfy the conditions of establishing perfect PR:

- 1 Non separability and non additivity. It is very difficult to identify and to separate the productive contributions of each input: is the success of a fashion collection, and if so to what extent, the result of the creator, of his or her assistants, of the top models, of the manager of the show, of the marketing managers...? We cannot relate $v_{o}$ to some precise action $\mathrm{A}_{\mathrm{jk}}$. Creative production is often a team production. Moreover, creation frequently 
uses heritage and it is thus difficult to separate new creativity and old creativity accumulated in heritage and used in the creation process. When Lagerfeld became the new director of Chanel, his first decision was to spend a lot of time visiting all the departments of the Chanel Maison to be impregnated by the heritage of the Maison. He did not want to copy Chanel but to be inspired by the Chanel style in order to create a new Chanel in the way of Coco Chanel (Roux, 2001). How can the new value be distributed between direct creative labour and cultural heritage assets, between $A_{j k}, A_{j k+1}$, $\mathrm{A}_{\mathrm{jk}-1}, \ldots$ ? Heritage assets are not standard inputs the value of which is determined by the market. And if the creator produces thanks to a social heritage, it is impossible to conceive a production function, incorporating that heritage, allowing evaluating marginal productivity. YSL learnt to draw by studying classical paintings and drew his inspiration from the models of Dior and Balenciaga, but a greater use of the "Dior input" would not have increased his output or improved its quality. And, considering the Mondrian collection how can one measure the net value of the YSL's creativity? Moreover, the creation function is generally not additive. Each input or condition of the production process may play a decisive role, according to the O-ring effect.

- 2 Non reproducibility. While production through the transformation of inputs is an operation which can be infinitely repeated by the productive consumption of the necessary inputs, creation appears as a particular phenomenon, founded on such a radical singularity that we cannot have a similar result by buying other inputs. The dresses of the Trapeze line by Christian Dior are behind us and now we can only have copies, or new models "in the touch of Dior" or "paying homage to Dior". We will never again have original Dior designs, whatever the consumption of inputs might be. Moreover, while production by the processing of inputs is an operation that can be repeated ad infinitum through the consumption of the necessary inputs, some creations arise as one-off phenomena that are so radically unique that no similar outcome can be obtained by buying further inputs.

- 3 Idiosyncrasy. The outcome of a creative process may vary with the environment or even at random. The same inputs sometimes yield a work of genius and sometimes a mediocre product; Galliano's performances were not the same every day. The relation $R_{j}-A_{j k}-v_{o}$ is not stable. The creation of the artist or of the fashion stylist is produced out of nothing, or out of an economic resource, or out of inputs, except for that unique, nonstandard resource, be it called genius, creativity, inspiration, or illumination. Yves Saint Laurent claimed that in the morning he daydreamed in his office and suddenly an idea came up to him; he then picked up a pen and sketched a garment. After nights out at discotheques John Galliano goes to his office when he has a "flash'; he summons his assistants and tells them of his visions; they get down to work and he goes off to bed. How can any true measure of their talent be established? As we are in an economy of infinite variety (Caves, 2000: 6), creative inputs do not operate in a standard way and the relation between resources and the value of their effects is often indeterminate. Furthermore, some creative inputs are so unique, specific, or idiosyncratic (e.g. the talent of John Galliano or Tom Ford) that their potential market is very small and does not provide a suitable and stable standard of reference.

- 4 Measurability of effects. Unique cultural creations with no technological dimension but with long-run effects are not amenable to comparison, and there is no scale of value 
for them in terms of their quality. A YSL dress is not a Balenciaga or a Poiret one, a Picasso is not a Poussin, and Borobudur is neither Chambord nor the Empire State Building. It would be nonsensical to try to rank these works by their quality or on any scale of creativity: is the invention of the Trapeze line in any way superior to the innovation of the miniskirt? Even if creators are acknowledged during their lifetime (e.g. Christian Dior ), how can their contribution be measured in monetary terms? How can one establish a relation between $R_{j}$ and $v_{o}$ ? And how can one differentiate between the value of a collection and its value for the development of fashion and design? The question is that much more difficult because many of the effects are non-market effects. Another point is that individual appreciations and the creation of social appreciation are highly changeable and unpredictable. This makes the value of such effects very random. The most important creations are often avant-garde and in opposition to the environment of the moment. The creator is often not acknowledged as a remarkable person and it is only later that his (or her) work becomes valuable. Moreover, the non ended effects of tangible and intangible cultural heritage assets generate further problems to measure value of the effects. Assigning value to creativity and to creativity accumulated in heritage resources is particularly difficult. It is difficult to know what effects a creation might produce across space and, a fortiori, over years. The different values of their uses have to be added up and the list of their effects is never complete because new effects may appear later on. This point is reinforced by the nonincrementality of creative processes. While technical objects disappear, the more recent supplanting the former, the purely creative good establishes a final result. It is not substituted by a new, better, powerful good. George Steiner noted that, while the progress of scientific and technical knowledge is cumulative, earlier works in art, literature and music are never superseded: "major art is not relegated to antiquarian status; Chartres does not date... What ... is in advance on Homer or Sophocles, on Plato or Dante? Beyond Hamlet, what novel surpasses Madame Bovary or Moby Dick? “ (Steiner, 2001: 252). Singularity and incomparability of creative goods -among which fashion goods- are opposed to the idea of an incremental development of science

and technology . Creativity also affects consumption by offering new goods and by influencing individual preferences. It does not correspond to an alignment on individual preferences but more often to the production of novel goods, previously unknown to consumers. What procedure can produce a rational or reasonable evaluation of such an effect, and capitalize that effect over years?

- 5 Dominance of creativity. In a creative process, creativity is the main input. Even if other inputs make significant contributions the end-result mainly depends on creativity because a creative producer obtains a very different result from a non-creative producer and increases the value of other inputs (the silk of the dress or the embroidery work). The specificity of creation is analyzed through the image of God's creation. God created the world because he made it out of nothing. In the same way, the creation of the artist or of the fashion stylist is made out of nothing, or out of an economic resource, but

25 Goods which mix creative production and technical properties simultaneously obey to the non-incremental property of creativity and to the incremental property of technology, in proportions related to the degree of the incorporated creativity. A research and development process is often closer to a standard production process than creation. The investment in $\mathrm{R}$ and $\mathrm{D}$ gives a probabilistic result. Products normally follow one another in a better way: the last version of software corrects the former bugs and improves some functions; the new type of car introduces some improvements. For creative goods that include technology improvements are possible: in the luxury industries, the "carré Hermès" silk or the Vuitton luggage is improved by new raw materials and more sophisticated treatments... 
thanks to the singular and non-standard resource, called genius, creativity, inspiration, and illumination. Modern times spread the idea of a creation linked to God to one linked to humanity. This notion is outside the standard field of economics. Unlike the production function, the technological combination is unknown and it is difficult to evaluate each input. The measure of time spent is nonsensical: What stake is it for social development that the Messiah of Haendel has been composed within a week, a month or a year? And what interest is there to seek reducing this length of time?

\subsection{How does creativity make it difficult to implement PR?}

The above-mentioned characteristics of the creation process lead to four types of difficulties:

1. To define the entitlement. The first problem in defining property rights is to identify all the resources (present and past including heritage), which currently have creative effects or can produce some effects in the future, to identify all the producers of resources, to separate their contributions, to distribute rights among them so as to give each producer exclusive rights in their resources and control over the effect of their creative contribution. As seen before, the problems of non-separability and non-additivity prevent the market or society from entitling perfect property rights. The identification and the sharing of the relations between effect, resource and holder are often problematic. It is not obvious to decide what can be appropriated and who can be defined as owner of a property right.

2. To organize a market for IPRs. In order to define property rights that can be transferred through a market process, resources have to be evaluated. But nonseparability, non-additivity, the dominance of creativity and the difficulties of measurability disrupt the evaluation of the effects of the resources. Idiosyncrasy is a characteristic of creativity that makes it even more difficult to infer the value of used resources from the value of their effects.

3. To enforce IPRs. The third problem is to enforce the definition, entitlement and transfer of property rights. As for the Mondrian dress created by Yves Saint Laurent this may be difficult. Piracy and opportunistic behaviour result from difficulties in identifying resources and in entitling them in order to define exclusive rights.

4. To justify IPRs. The difficulties to clearly define and valuate the productive resources and their holders imply difficulties to justify the present distribution of property rights. Normative problems arise. Is it fair to give the main part to the creator? Or to the owner of the firm? As usual in the field of intellectual property rights, the distribution of monetary earnings is far from contributing to human happiness or social development is it fair that Einstein's income was so small compared to that of Bernard Arnault?

These difficulties to implement property rights are more or less important according to the characteristics of the goods and of their creative process. In a first type of situations, the relation between the resource and the value of its effects is not problematic and the entitlement of resources is enough to define the relation between the holder and the uses of the resource (property rights in perfumes are well defined).

In the second type, the relation is more difficult to define and to evaluate but the effects remain in the private domain. Great fashion creators benefit from their creative image, from a capital of reputation and from a symbolic power. Private assets are formed in this way. They 
nourish many other goods such as perfumes and luxury goods, and trademarks can capture their main economic consequences. Firms have portfolios of patents and brands and manage these assets by selling or licensing them.

In the third type other firms or actors can capture some effects. This is the case when the difficulties to define the entitlement lead to difficulties to enforce PRs, allowing piracy or copying.

In the last cases, the effects flow over into the public area, as with paintings or science. In the fashion industry these diverse cases exist and often overlap. Thus, strategies and power play a key role in the management of IPRs.

\section{The classic model of management of cultural assets in the Haute Couture industry}

To understand the problems of IPRs in the classic system of fashion we first have to consider the old system, the fashion model of the Royal Court. The producers were dressmakers (couturiers and couturières) who mainly reproduced the 'canons de l'étiquette'. The main source of inspiration was the common heritage of designs. There was not a creative process but only a production process and no IPR was thus at stake. 'Novelty' was introduced at the Court by the courtiers who encouraged their dressmakers to innovate within the étiquette rules. Others imitated them if the Grands or the King (the 'arbitres des élégances') accepted it.

The Classic model of the couturier-créateur results from the coming to power of the creator. Creation is a team production but the couturier-créateur has the pre-eminent role and an absolute power over the creation process.

The creativity of craft workers fades away in the products of the Maison. They can make suggestions or create new technical solutions but their creativity disappears in the collective product. Obviously their wages include bonuses for the recognition of their skill but they are not related to particular innovations or ideas. They also benefit from collective training. The heritage of collective knowledge benefited the individuals through training and the ambient culture. It was therefore partly encapsulated in the skills of individuals, increasing the value of their skills, and circulating with them when they changed employers. In this collective heritage no IPRs coming from past work and present creativity existed although this heritage operated much like capital.

To some degree too the craft heritage was a club product (know-how, routines, procedures, etc.), arising from synergies and associated with the specific style of the Maison. The creator (or the Maison) had an implicit IPR in the usus and the fructus of this club heritage but no explicit IPR and therefore no IPR in its abusus. Accordingly it was usually not transferable. Its value was reproduced through the training of new employees coming into contact with the older ones in the Maison. If the Maison happened to disappear, the collective specialized knowledge was generally lost. To some extent the heritage of the craft knowledge was also the collective and common heritage of the Parisian fashion district, with open access but only within that district.

The Maisons paid for labour and raw materials and the creator was the residual claimant as a consequence of his domination: the creator took the main role and submitted all the other inputs. Creativity appeared to be an attribute of the creator, the couturier-créateur, even if others (e.g. stylists and managers) did also contribute to these creative acts. The creator owned 
his individual skill and had a partial IPR (usus and fructus) in the collective creative skill to which he greatly contributed. The creative products and their heritage assets included specific models and general styles. In France, the dessins et modèles law protected particular models. These IPRs were weakly enforced and foreign buyers could copy the designs but as the designs were associated with the creator's style they were not very useful in other styles. Moreover, infringements were of little consequence because the relationship between customers and producers was a personal and not a market relationship. Customers addressed their demand directly to bona fide producers. As competition among creators runs by differentiation and as each creator seeks to constitute a clientele, he has to develop an original style instead of copying. And, when copying did occur, IPRs would not provide much of a solution because it would have been very difficult to prove that one stylist had been copying another one instead of having been inspired by the same social and cultural atmosphere or by the common cultural heritage of fashion.

As materials were expensive, piracy was difficult and mainly concerned off-the-peg clothes, which was not the core business of Haute Couture. Here again, the styles were too closely associated with the personality of the creator-founder, who was the owner and head of the fashion firm. As far as the image of the creator is concerned, the reputations built up were internalized in the firm and protected by a trademark. This trademark was not a market IPR but a personal IPR taking the form of a griffe (the creator's name). The griffe expressed the individual creativity of the couturier and constituted a heritage that was transferable among products, hence the success of derived products (accessoires), but not among firms. When the firm disappeared, the reputation heritage assets, the value of which was idiosyncratic, disappeared too.

The most important place for piracy was in the ready-to-wear system. Here was a real possibility for ready-to-wear producers to copy designs of Haute Couture garments. And it was actually the case. But these copyists did not compete with the original creators because the outlets of the Haute Couture were reserved to original and legitimated creators within a system of personal relations. Ready-to-wear constituted a different market. Obviously copying made them avoid paying royalties to the Maisons. The loss was not very important because ready-towear was, before the Second World War, in most countries limited to a supply of low quality goods. In any case creators considered themselves as artists and not as money-makers.

Therefore the main institution that protected creativity, reputation and investments to develop outlets was the heritage itself of the creators. Each creation was related to a specific creator, a specific style and a specific reputation.

But personal heritages could not readily be passed on. Creative knowledge and the corresponding heritage were idiosyncratic. The Maisons were closely connected with the personality of the founder and no distinction was possible between the person of the creator and his creative heritage. Cultural heritage assets could thus not be allocated as autonomous resources and no property rights could be entitled for them. Many Maisons disappeared when the creator died and no successor creative enough could often be found. As the population of these firms was highly unstable and as some firms disappeared, this kind of heritage was often lost. In most cases, the market failed to organize the transfer and re-allocation of these heritage assets. In short, these assets were hardly transferable, often disappeared upon the death of the creator, and were lost.

No IPRs existed in heritage of collective creative knowledge either but it was linked to a special area, a certain Parisian district, which protected it from absolute unregulated access.

Other common heritage assets (including styles, tastes, institutional and cultural 
heritage) were the common property of the French fashion system. No IPRs protected them but their use presupposed an idiosyncratic connection with this system.

To conclude on the classic management model, IPRs could be low and badly defined without any substantial loss of efficiency in the current period. Therefore this resulted in substantial losses over years:

- when the firm was handed down over years heritage assets were internalized

- when the firm disappeared the market transfer of heritage assets was generally impossible.

Moreover this system was only effective because the relations between demand and supply were personal relations within a small circle of people, the social elite (cf. annexe 1). In the new model of the fashion market, financial groups in the luxury goods industry purchase the Maisons but are interested in mass outlets. The set of problems concerning IPRs is consequently changing.

\section{The new model of IPR set by the luxury groups and the new challenges}

\subsection{A set of new problems}

The new financial groups in the luxury goods industry are very keen to enhance the value of the creative and heritage assets of the Maisons and develop a more rigorous style of management. They are confronted with three key problems.

The first one is the increase in the value of creativity that accompanied the expansion of the fashion field and its closer association with all other luxury goods. The second one is the reproduction of the value of their heritage assets by the groups over years. They now operate by a long-term, managerial logic, and no longer by the cultural and individual logic of the grands couturiers. The third one is the transfer of rights in heritage assets between firms or groups, at some point in time. Solving these three problems requires new IPRs. IPRs have to be better defined in such a way that creative assets and their connected heritage assets could really be protected and exploited. They have to be separated from the person of the creator so that they can be passed on, either over years or across space, within the group or within the market. Heritage assets have to be enhanced. So the fashion market model implies a better definition of IPRs in creative heritage assets and the emergence of a market for them.

Firms continue to benefit from the private club heritage of craft knowledge, but the main change occurs when this knowledge is kept within the firm or the group over the long term. This is the case of accessory makers like Hermès or Vuitton. Great attention is paid to the training of workers. Their narrow specialization in the firm's products prevents the formation of an external labour market. So the lack of specific IPRs in club heritage assets does not prevent their transfer within firms over years. At a certain point, this private club heritage may be transferred through the market. New luxury groups take control of existing firms to develop their production of accessories.

An important source of value for these groups is that of creative knowledge heritage assets but these cannot be separated from the personality of their creators and they cannot be managed as standard inputs and transferred over years like capital. Transferring them after the death of the founder-creator, implies separating the creator's name and his name as a person. The trademark provides a solution: Dior is a world-famous trade mark (and was given as a first name to more than one hundred children born in 2010) but Christian Dior died 50 years ago. The trademark is no longer the griffe. Nevertheless, this process is not easy. 
To produce new creative products from the heritage assets of creative knowledge and products implies organizing a new idiosyncratic link between the heritage of a Maison de couture and a new creator, capable of reproducing the value of this resource. Lagerfeld has to maintain and expand the value of Chanel's creative heritage, Galliano that of Dior, and so on. When Lagerfeld arrived at Chanel he started studying the Chanel style for several months. How to define Chanel style? how could new goods bearing the Chanel brand be made identifiable as continuing the Chanel spirit? If successful, the heritage assets are a source of value, otherwise the potential value is lost. The value of IPRs in the non-cumulative cultural heritage assets is only a potential value and cultural heritage assets are not standard economic resources able to circulate by themselves in a market. This fact increases the importance of the work of new stylists and their key position in the firm. Managers must allow creators to express their creativity, despite their possible unconventional behaviour.

These creators acquire a new specific asset, namely their ability to maintain and expand the value of heritage assets. Accordingly a market for these skills emerges, but it is a narrow one. When Tom Ford and Domenico De Sole announced they were leaving Gucci, the staff began to look for successors but, as they themselves said, there were few potential candidates. Moreover, creators may benefit from a normal staff turnover according to market incentives. These incentives are as important as a market for stylists is emerging. They are also necessary to allow for some renewal among creators. Managers seek to prevent opportunistic behaviour by giving creators a share in profits or in the capital, which means sharing the IPRs with them. Sophisticated contracts manage the relations between great creators and their groups. Galliano has a share in Dior's profits and capital and so he has an incentive to use Dior's heritage efficiently. At first he was authorized to develop his own firm, but afterwards LVMH preferred to take the control of this firm. Internal monetary incentives to be creative may be outdone by external - market - monetary incentives to change jobs.

Lastly, IPRs do not allow a strictly and clearly separate use of Dior's heritage for producing Dior goods and for producing Galliano goods. There is thus a "hold-up" problem. Dior's heritage contributes to increasing Galliano's reputation and not only the firm's reputation. The owner of the heritage (the firm) is not the sole user of the heritage and cannot precisely organize its utilization by its employees, including the creator. So the economic links between old heritage assets, new heritage assets, creators and firms are very important but the legal links are at this moment not enough to manage them all. Contracts and IPRs remain incomplete. And problems remain, as with the break up between Tom Ford and the Pinault group.

\subsection{Reputation heritage assets: from name to trademark}

The reputation heritage assets procure increasing value for luxury goods industry groups in which the market for luxury goods moves into mass production. Groups are thus keen to strongly enforce IPRs in trademarks.

These IPRs allow them to use their pre-existing reputation for new types of products: they obviously create new accessories in order to propose an all-round set of luxury goods to consumers (Vuitton does not produce only luggage but also bags, shoes, pens, watches, and so on; Hermès has added a garment collection designed by Jean-Paul Gaultier to its traditional accessories). IPRs also allow for corporate restructuring in this growing industry.

Another important objective of these groups concerns the image heritage of the Maisons: the names of Dior or Saint Laurent are still a sign of quality and creativity, and fashion goods are semiotic goods. But their creators are dead or retired. The problem of the present owners is to transfer the positive image of the great creators who founded their Maisons to the name of the firms. They must start from the fashion designer's name - the griffe (an 
association between the creative products and the name of the creator, a personal IPR) - and move to the trademark (an association between the products and the name of the firm, a market IPR). This transfer allows the value of the designer's name to be extended over years and space. The value outlizes the grand couturier and extends beyond a particular work to cover the whole

product range. The groups organize communication policies to enhance the reputation of the trademark: creation of museums or exhibitions (e.g. Yves Saint Laurent and Giorgio Armani at the Guggenheim), purchasing of stores on the main squares of the world's major cities.

The capitalization of heritage in trademarks as brand names allows the transfer of IPRs in reputation heritage assets. Financial groups can buy and sell firms and associated trademarks: Gucci's heritage value can be used both by PPR and by the LVMH groups because Gucci is no longer a creator's name but a brand name. Nevertheless, the value of trademarks is very uncertain: in 1977, the sales of the Armani women's collection were 800 million lire; three and half years later they were 40 billion. And how can a trademark be valued when the creator is dead or has left? What would be the value of Cardin's enterprises without Pierre Cardin or of YSL without Saint Laurent, or Gucci without Tom Ford? And how can the value of Gucci be split between Tom Ford, the creative stylist, and Domenico de Sole, the creative manager?

Another problem is that the use of the existing reputation to provide accessories, and the change in the nature of IPR in the fashion industry from the griffe as a personal IP to the trademark - give space for some specific kinds of infringement concerning trademark, mainly in the field of luxury accessories. Indeed, for instance, handbags, belts and other accessories branded with a famous trademark are more often the prey of copying activities.

\subsection{Creative piracy and vulgarization of creation}

There are two main types of creative piracy.

The first one is piracy by firms and countries that simply copy designs and models and supply a less expensive product. They save on creative labour and sometimes use inferior quality materials. This kind of piracy benefits from relatively low wage costs. French and Italian professional institutions have obtained the adoption of "designs and models" legislation, immediately applicable, in their respective countries. Moreover, as previously noted, at the European level, the Council Regulation n6/2002 of 12 December 2001 on Community Designs entered into force on 6 March 2002. Professional institutions feared that European enlargement would lead to a marked upturn in piracy.

A second type of piracy is the creative piracy of mass fashion. The protection of designs and models cannot, at the moment, prohibit the use of new models of Haute Couture by the manufacturers of mass fashion. It can prohibit complete product piracy: a firm cannot sell a garment labelled Saint Laurent unless it has been produced in the Saint Laurent workshop. But, under the present legal system, nobody can prohibit street fashion from copying the style and specificities of a Haute Couture model. And new fashion technologies enable even faster copying. Professionals refer to the example of the Zara fashion model: two weeks after the Haute Couture and prêt-à-porter collection fashion parades in Paris, one can find very similar products in Zara shops. IPRs are inoperative against this kind of copying:

- The test of the "likelihood of confusion" (well known in the European jurisprudence

3 The value of the brand image is especially important for some products in the luxury goods industry such as perfumes. In the case of the perfumes of the French Haute Couture firms, the value of raw materials represents less than 10 per cent of the price; the greatest value is imparted by the brand image and the general image of French luxury goods. 
on trademarks ${ }^{27}$ ) can help us to explain why such a copying activity cannot be pursued. There is no possible confusion on the part of consumers between the products for several reasons. First, in the case of Zara, the strategy used does not consist in close-copying of the original products of the Haute Couture, what would be sued on the account of infringement of design ${ }^{28}$. Secondly, there is no copy of a registered sign as Chanel or YSL - what could be condemned at the national level or at the European one accordingly the office that registered the trademark. The garments sold by Zara shops are labelled as Zara's. So there is no doubt for the public on the origin of the clothing products, as these ones are sold by Zara shops the consumers cannot think that the products come from the Maisons de couture. There is only an inspiration or imitation of a style, colours, symbols or materials. Thirdly, the prices and the quality of the products are very different so that the consumers cannot think that they are buying the products presented in the fashion parades in Paris. By adopting such a strategy, mass fashion manufacturers can therefore save on creative work and confine themselves to adjustment work.

- On the other hand, as in the age of the dress-creator it would be very difficult to prove that one stylist has been copying from another one and it is even more difficult when creation is inspired by the social and cultural atmosphere. Some firms are specialized in the production of trend selections (cahiers de tendances). It is nevertheless common knowledge that creative piracy is systematically organized. Trade organizations are lobbying for a better protection of IPRs, first and foremost within the European legal system.

Another means of combating both types of piracy is to play on consumers' preferences. The policy of Haute Couture and prêt-à-porter de luxe firms is thus a communication policy to persuade consumers of the social value of a brand. Simultaneously it is a policy to increase the brand's value, to differentiate it from the standard brands and promote it as a luxury brand, if possible a star or superstar brand.

\subsection{IPRs in common heritage assets}

The two main issues here are to manage common heritage assets so that they can be reproduced over years and to make them productive.

The common heritage of craft knowledge is a configuration of specific assets. They are closely associated with a local geographical context and are non-transferable assets. No market can be organized for them and no IPRs can exist. These assets are formally freely accessible but, in fact, can only be used if firms choose a local installation. Geographical localization constitutes an entry barrier and creates an idiosyncratic relation for firms currently benefiting from these assets. One major consequence of the lack of property rights in this heritage is the absence of any economic management of it. Nobody is responsible for the reproduction of the heritage over years and firms can operate as free riders. In fact, the crisis in Haute Couture has led to a contraction of the craft sector traditionally linked to it and to the loss of highly qualified skills. Public policies are required to manage the economic value of these heritage assets. The

27 In particular with the Arsenal case (case C-206/01, Arsenal Football Club plc v. Matthew Reed, Judgment of the European Court of Justice (ECJ), 12 November 2002), the Opel case (case C-48/05, Adam Opel AG v. Autec AG, Judgment of the ECJ, 25 January 2007) and the Picasso case (case C-361/04P, Ruiz-Picasso e.a. v. OHIM, Judgment of the ECJ, 12 January 2006).

28 On the contrary, in the United States, the situation is quite different, mainly because no protection is currently provided to fashion designs. "Fast-fashions copyists", like the retailer Forever 21, provide products that are precise copies of American famous designers's products (Hemphill and Suk, 2009, 1172-1174). 
institutional heritage of the Maison de Haute Couture model is not legally protected either. It may be duplicated abroad but it is connected to the specificities of the Parisian fashion district and to its specialization in a very restricted sphere of the fashion system, that of Haute Couture.

The creative knowledge heritage is also locally embedded, but is not controlled by any market or any property rights. It favours French firms but foreign ones can benefit from it by relocating in the Parisian district, by purchasing French firms and by hiring creators who have benefited from this creative atmosphere. The common heritage of styles is a common one but represents a higher value for the firms that produce culturally similar creations. No IPR is defined in these assets and free access is the rule. The same is true for the common heritage of tastes, the semiotic and image heritage of Parisian Haute Couture, and the French touch. Accordingly, French firms attempt to associate the image of French luxury goods closely with their brands: advertising for perfumes invariably states the brand and the name of Paris. This is currently the only way to avoid piracy and the proliferation of pseudo "Made in Paris" commodities. In the future, there may be a local protection of geographic origin: some firms and institutions would like to obtain some form of protection and draw up legal strategies.

To increase the productive uses of these common heritage assets both public and professional policies are implemented. Museums and exhibitions maintain and expand the semiotic and image heritage. They improve the image of the country and of its creative products as in the case of the "young British artists" campaign. Professionals now think that cultural institutions and policies have a big economic impact on fashion and luxury goods industries. They organize industrial policies and partially transform common heritage assets into collective heritage assets, with a collective partial management.

Luxury goods groups like LVMH and PPR are particularly interested in the image of creativity conveyed by these creations and develop sophisticated and expensive communication policies. They appropriate a part of the common heritage of the age of aristocratic luxury and transform it into a market and into democratic luxury. In the present new age, mass markets need powerful images for their goods. The use of heritage is therefore an essential competitive resource. Even so, the common character of the reputation of Haute Couture leads to some difficulties. Financial groups in the luxury goods industry are mainly interested in the earnings from accessories (perfumes, bags, shoes, watches, pens and so on). Haute Couture itself is no longer profitable but its creativity is the origin of image and reputation effects. There is therefore a contradiction: reproducing reputation heritage entails reproducing the creativity of Haute Couture, but these groups are seeking to disinvest in Haute Couture. And private strategies can lead to free riding: every group wishes to benefit from the reputation but none of them are willing to invest in Haute Couture. This problem is serious because reputation in creative industries is unstable. For instance, the idea that French creativity has been superseded by Italian creativity may easily become a commonplace and lead to bandwagon effects. Private groups are therefore calling for collective and public policies ${ }^{29}$.

\section{Concluding remarks}

We cannot argue that the persistence of a low system of IPRs in the fashion industry derives from its efficiency. It is mainly the result of the characteristics of the inputs that are used in the creative production process.

As long as creativity and heritage play a decisive role in the creative process, a standard PR system cannot be implemented. The characteristics of creativity constitute strong constraints for defining, entitling, legitimating, enforcing, valuating and exchanging property rights. The

\footnotetext{
${ }^{29}$ The appendix 1 recapitulates the ways of protection in the two models.
} 
replacement of the elitist model of the couturier-créateur by the market model of fashion leads to a development of IPRs to organize the protection and allocation of creative resources, and particularly of cultural heritage assets the value of which is increasing. The specificities of such heritage assets however prevent from the building up of a market for IPRs in cultural heritage assets. The standard model of property rights, founded on the paradigm of the production function and of the consumption function, is partially irrelevant here, depending on the specificities of the cultural heritage assets. Four types of problems are linked to creative cultural heritage assets. The first one is the common character of many of these assets, which involves the incompleteness of the property rights to be defined (e.g. the case of the Mondrian collection). The second problem is the difficulty of separating these cultural heritage assets from the individual persons who built them to organise exclusive property rights. A third limit can be found in the transferability of these property rights, and the fourth problem is related to the difficulty of enforcing property rights in these assets. Finally, these difficulties linked to the definition and the implementation of property rights in cultural heritage assets require economic actors to develop strategies concerning the uses of cultural heritage assets in order to obtain earnings. At the same time the spectacular growth of the industrial street fashion constitutes a new challenge for the luxury groups. The limits of existing IPR allow street fashion firms to use creativity developed in the other segments of the fashion system that can in the long run erode the creative component of the fashion. 


\section{References}

Alchian A.A. and H. Demsetz, 1973, The Property Right Paradigm, The Journal of Economic History Volume 33, Issue 1: The Tasks of Economic History, March 1973: 16-27.

Atkinson N., 2009, Copycats: A Tale of Two Jackets, National Post Online, April 23, 2009 and May 13, 2009.

Barnett J.M., G. Grolleau and S. El Harbi, 2010, The Fashion Lottery : Cooperative Innovation in Stochastic Markets, Journal of Legal Studies, 39.

Barrère C. 2007a "Les industries du luxe, des industries du patrimoine?", Economie appliquée, numéro spécial "L'économie du patrimoine", 2007/3.

Barrère C. 2007b "Vers une théorie économique du patrimoine, une approche substantiviste", Economie appliquée, numéro spécial "L'économie du patrimoine", 2007/3.

Barrère C. and W Santagata, 2005, La mode, une économie de la créativité et du patrimoine à l'heure du marché, Paris, La Documentation Française.

Barrère C. Barthélémy D. Nieddu M. Vivien F-D. (eds), 2004, Réinventer le patrimoine, L'Harmattan, Paris, pp. 109-120.

Benghozi P.J. and W. Santagata, 2001, Market Piracy in the Design-based Industry: Economics and Policy Regulation, Economie Appliquée, LIV, n³, septembre 2001: 121-148.

Buccafusco C. J. 2008 "On the Legal Consequences of Sauces : Should Thomas Keller's recipes per se Copyrightable ?", Cardozo Arts and Entertainment Law Journal, 24, pp. 1121-1156.

Caves R E., 2000, Creative Industries. Contracts between Art and Commerce, Cambridge (Mass.), Harvard University Press.

Conner K. R. and R. P. Rumelt, 1991, Software Piracy: An Analysis of Protection Strategies. Management Science, 37 (1991): 125-139.

Cox, C., J. Jenkins, 2005, Between the seams, a fertile commons: An overview of the relationship between fashion and intellectual property. Norman Lear Center Publication, Duke University Law School, Durham, NC, 4-20.

Fauchart E. and E. von Hippel 2008 "Norms-Based Intellectual Property Systems: The Case of French Chefs", Organization Science, 19(2), pp. 187-201.

Fischer Fridolin, 2008, Design law in the European fashion sector, WIPO Magazine, January-February, ${ }^{\circ} 1$, pages 12-13

Grumbach D., 1993, Histoires de la mode, Paris, Le Seuil.

Hallet Margaret, 2008, Fashion Design: Thinking across boundaries, University of Connecticut School of law, power point slides.

Hemphill C. Scott and Jeannie Suk, 2009, The Law, Culture, and Economics of Fashion, Stanford Law Review, Vol. 61, March, 1147-1199.

Hetherington S. L., 2001, Fashion Runways are No Longer the Public Domain: Applying the Common Law Right of Publicity to Haute Couture Fashion Design, 24 Hastings Comm. \& Ent. L. J. 43 (2001)

Lehnert G., 2000, A History of Fashion in the 20th Century, Cologne, Konemann.

Litman, J., 1994, Copyright in the Twenty-First Century: The Role of the Copyright Office, The Exclusive Right to Read. 13 Cardozo Arts \& Ent. L.J. 29 (1994)

Madison M. J., B. M. Frischmann, and K. J. Strandburg 2010 "Constructing Cultural Commons in the Cultural Environment". Cornell Law Review, Vol. 95: 657-710.

Nelson R.R. and S. Winter, 1982, An Evolutionary Theory of Economic Change, London, The Belknap Press of Harvard University.

North D., 1981, Structure and Change in Economic History, New York: Norton.

OECD 1998, The Economic Impact of Counterfeiting. Report.

Ostrom E. 1990 Governing the Commons: The Evolution of Institutions for Collective Action. Cambridge University Press.

Raustiala K. and Chris Sprigman, 2006, The Piracy Paradox: Innovation and Intellectual Property in Fashion Design The John M. Olin Program in Law and Economics Working Paper Series, Year 2006, Paper 29, University of Virginia Law School

Roux E., 2001, "La conciliation des contraires : créativité et rigueur dans la gestion de l'identité d'une marque", communication au colloque La mode, un laboratoire de créativité, Turin, ICER, octobre 2001.

Rutter J. and J. Bryce The Consumption of Counterfeits Goods 'Here Be Pirates'? Sociology. December 2008, vol. $42, n^{\circ} 6,1146-1164$.

Santagata W. 2002 "Cultural districts, property rights and sustainable economic growth". International Journal of Urban and Regional Research, $\mathrm{n}^{\circ} 26$, pp. 9-23.

Santagata W. 2006 Cultural districts and their role in developped and developing countries. In Ginsburgh V. Throsby D., Handbook of the Economics of Art and Culture, North-Holland, pp. 1101-1119.

Schmidt-Szalewski J. et J-L. Pierre, 2007, Droit de la propriété industrielle, 4ème édition, Litec. 
Shemtov N., 2007, “Trade mark use' in Europe: revisiting Arsenal in the light of Opel and Picasso", Journal of Intellectual Property Law \& Practice, 2(8), 557-563.

Steiner G., 2001, Grammars of Creation. New Haven, Yale University Press. French translation: Grammaires de la création, Paris, Gallimard.

Terakura K., 2000, Insufficiency of Trade Dress Protection: Lack of Guidance for Trade Dress Infringement Litigation in the Fashion Design Industry, 22 U. Haw. L. Rev. 569, 618-19 (2000).

Throsby D. 2010 The Economics of Cultural Policy. Cambridge University Press.

Throsby D., 2001, Economics and Culture, Cambridge, Cambridge University Press.

Towse R. 2010 A Textbook of Cultural Economics. Cambridge University Press.

WIPO, 2005, IP and Business: Intellectual Property in the Fashion Industry, WIPO Magazine, May-June, n³, pages $16-19$

Yeh Brian T., 2010, Copyright protection for Fashion Design: A Legal Analysis of Legislative Proposals in the 111th Congress, September 3, 2010, Congressional R 


\begin{tabular}{|c|c|c|c|c|c|c|}
\hline $\begin{array}{l}\text { INSTITUTI } \\
\text { ON }\end{array}$ & $\begin{array}{c}\text { TO BE } \\
\text { PROTECTED }\end{array}$ & STAKES & $\begin{array}{l}\text { WAY OF PROTECTION } \\
\text { CLASSIC MODEL }\end{array}$ & $\begin{array}{l}\text { EFFECTI- } \\
\text { VENESS }\end{array}$ & $\begin{array}{c}\text { WAY OF } \\
\text { PROTECTION } \\
\text { NEW MODEL }\end{array}$ & $\begin{array}{c}\text { EFFECTI } \\
- \\
\text { VENESS }\end{array}$ \\
\hline \multirow{4}{*}{$\begin{array}{l}\text { Haute } \\
\text { Couture } \\
\text { couture }\end{array}$} & $\begin{array}{l}\text { Craft workers } \\
\text { competence }\end{array}$ & & No special protection & Nil & $\begin{array}{l}\text { Strategy of } \\
\text { reproduction }\end{array}$ & \\
\hline & $\begin{array}{l}\text { Creativity } \\
\text { styles } \\
\text { Creativity } \\
\text { designs }\end{array}$ & \multirow{3}{*}{$\begin{array}{l}\text { Firms are subjected to } \\
\text { - Copying by standard } \\
\text { Ready to Wear } \\
\text { - Creative piracy of the } \\
\text { Street fashion }\end{array}$} & \multirow[t]{3}{*}{$\begin{array}{l}\text { Protection by the creator's } \\
\text { heritage and the personal } \\
\text { relations }\end{array}$} & \multirow[t]{3}{*}{$\begin{array}{l}\text { Strong but } \\
\text { limited in } \\
\text { the time }\end{array}$} & $\begin{array}{c}\text { Trademark } \\
\text { Designs and Models } \\
\text { law }\end{array}$ & Low \\
\hline & $\begin{array}{l}\text { Reputation } \\
\text { heritage }\end{array}$ & & & & \multirow{2}{*}{ Trademark } & Strong \\
\hline & $\begin{array}{c}\text { Outlet } \\
\text { production }\end{array}$ & & & & & Medium \\
\hline \multirow{4}{*}{$\begin{array}{l}\text { Haute } \\
\text { Couture } \\
\text { accessories }\end{array}$} & $\begin{array}{l}\text { Craft workers } \\
\text { competence }\end{array}$ & & No special protection & Nil & & \\
\hline & $\begin{array}{l}\text { Creativity } \\
\text { styles } \\
\text { Creativity } \\
\text { designs }\end{array}$ & \multirow{3}{*}{$\begin{array}{l}\text { Firms are subjected to } \\
\text { - Counterfeiting } \\
\text { - Creative piracy and } \\
\text { imitation }\end{array}$} & \multirow{3}{*}{$\begin{array}{c}\text { Protection by the creator's } \\
\text { heritage }\end{array}$} & \multirow{3}{*}{ Low } & $\begin{array}{c}\text { Trademark } \\
\text { Designs and Models } \\
\text { law }\end{array}$ & Low \\
\hline & $\begin{array}{l}\text { Reputation } \\
\text { heritage }\end{array}$ & & & & Trademark & Strong \\
\hline & $\begin{array}{l}\text { Outlet } \\
\text { production }\end{array}$ & & & & Trademark & Medium \\
\hline \multirow{3}{*}{$\begin{array}{l}\text { Luxury } \\
\text { Ready to } \\
\text { wear }\end{array}$} & $\begin{array}{l}\text { Creativity } \\
\text { styles } \\
\text { Creativity } \\
\text { designs }\end{array}$ & $\begin{array}{l}\text { Firms are subjected to } \\
\text { and can use } \\
\text { Creative piracy and } \\
\text { imitation }\end{array}$ & \multirow{3}{*}{$\begin{array}{l}\text { Protection by the creator's } \\
\text { or the stylist's heritage }\end{array}$} & \multirow{3}{*}{ Low } & Trademark & Low \\
\hline & $\begin{array}{l}\text { Reputation } \\
\text { heritage }\end{array}$ & \multirow{2}{*}{$\begin{array}{l}\text { Firms are subjected to } \\
\text { and can use Piracy }\end{array}$} & & & Trademark & Strong \\
\hline & $\begin{array}{l}\text { Outlet } \\
\text { production }\end{array}$ & & & & Trademark & \\
\hline \multirow{2}{*}{$\begin{array}{l}\text { Standard } \\
\text { ready to wear }\end{array}$} & $\begin{array}{l}\text { Reputation } \\
\text { heritage }\end{array}$ & \multirow{2}{*}{$\begin{array}{l}\text { Firms are subjected to } \\
\text { and can use Creative } \\
\text { piracy and Imitation }\end{array}$} & \multirow{2}{*}{ Trademark } & \multirow{2}{*}{ Low } & \multirow{2}{*}{ Trademark } & \multirow{2}{*}{ Low } \\
\hline & $\begin{array}{l}\text { Outlet } \\
\text { production }\end{array}$ & & & & & \\
\hline \multirow{4}{*}{$\begin{array}{l}\text { Street } \\
\text { fashion }\end{array}$} & $\begin{array}{l}\text { Managerial } \\
\text { creativity }\end{array}$ & $\begin{array}{l}\text { Firms are subjected to } \\
\text { and can use Imitation of } \\
\text { the business model }\end{array}$ & \multirow{4}{*}{ No special protection } & \multirow{3}{*}{ Nil } & No protection & Nil \\
\hline & $\begin{array}{l}\text { Creativity } \\
\text { styles and } \\
\text { designs }\end{array}$ & $\begin{array}{l}\text { Firms use Creative } \\
\text { piracy }\end{array}$ & & & Trademark & Low \\
\hline & $\begin{array}{l}\text { Reputation } \\
\text { heritage }\end{array}$ & \multirow{2}{*}{$\begin{array}{l}\text { Firms are subjected to } \\
\text { and can use Creative } \\
\text { piracy and Imitation }\end{array}$} & & & Trademark & Strong \\
\hline & $\begin{array}{l}\text { Outlet } \\
\text { production }\end{array}$ & & & & Trademark & Low \\
\hline
\end{tabular}




\begin{tabular}{|c|c|c|c|c|c|c|}
\hline \multirow{4}{*}{ Commons } & $\begin{array}{l}\text { Craft workers } \\
\text { competence }\end{array}$ & Open access & \multirow{4}{*}{$\begin{array}{l}\text { No legal protection } \\
\text { Protection as a district } \\
\text { heritage: cultural barriers } \\
\text { and transaction costs }\end{array}$} & \multirow{4}{*}{ Strong } & \multirow{4}{*}{$\begin{array}{l}\text { No legal protection } \\
\text { Protection as a } \\
\text { cluster heritage: } \\
\text { cultural barriers and } \\
\text { transaction costs }\end{array}$} & \multirow{4}{*}{ Medium } \\
\hline & $\begin{array}{c}\text { Creative } \\
\text { knowledge }\end{array}$ & heritage & & & & \\
\hline & Reputation & \multirow[b]{2}{*}{$\begin{array}{l}\text { Creative piracy and } \\
\text { Imitation }\end{array}$} & & & & \\
\hline & $\begin{array}{l}\text { Influence on } \\
\text { tastes and } \\
\text { preferences }\end{array}$ & & & & & \\
\hline
\end{tabular}

Appendix 1 